\title{
INVESTING IN PRESCHOOL AGE CHILDREN - A CASE STUDY OF VIDZEME REGION (LATVIA)
}

\author{
Feliciana Rajevska \\ Katrīne Reima \\ Vidzeme University of Applied Sciences, Latvia
}

\begin{abstract}
Social investments are important for a child's development and future success. Parental leaves and Early Childhood Education and Care services (ECEC) are among main forms of social investment, contributing to child poverty reduction and increasing equality, as well as underpinning the potential for skilled workers in the future. The aim of the paper is to analyse availability of the main forms of social investment in preschool age children - early childhood education services and parental leaves, in Vidzeme region (Latvia) for a case study. An analysis of policy documents, parents' surveys at pre-school institutions, interviews with education institution representatives and local authorities regarding education and social matters were conducted in the research. The support system for parents is still dominated by the "passive" form of support system. However, social investment policies are becoming increasingly more important. This is achieved by supporting parents' access to social investment services and by increasing the amount of parental leave benefits. In 2013-2015 funding for child-care and family policy has increased. Expenditure growth was mostly affected by an increase in the allowance for childcare and the minimum parental allowance. The availability of ECEC is moderate, but since 2009 private institutions and since 2013 babysitting services have been co-funded at the national level till May 31, 2016 to improve it. Since September 2015 a 3-year innovative project "Vouchers for the provision of child minder services to workers with nonstandard work schedules" has been introduced too, to promote parental employment and work and family balance. In Vidzeme region, for example, service availability is additionally stimulated by free transport services, ECEC fee discounts for poor, low-income and large families, etc. Results show that the availability of ECEC has been improved and there has been signs of positive changes in children's development. Nevertheless, the availability of ECEC is moderate, and in some poorer municipalities in Latvia Matthew effects can be spotted - the middle and highest strata of society use services to a higher extend then the low-income society.
\end{abstract}

Keywords: low-income families; Matthew effect; parental leave, pre-school education, social investment.

\section{Introduction}

Over time, the vision of support to families with children has changed, and this has happened mainly due to changes in family patterns. A two-earner family 
model has become increasingly urgent. (Morel et al., 2012) Since the late 1990's social investment policies have become more crucial in European policy, and family support policies put more emphasis on facilitation of work and family life. That has led to shift from passive to active forms of support to families. (Ghysels \& Lancker, 2011)

Early childhood, when brain plasticity and neurogenesis are very high, is an important period for cognitive and psychosocial skill development that is why investments and experiences during this period create the foundations for lifetime success. (Gertler et al., 2014) A growing number of research studies show that investments made precisely in this age has the highest returns, especially for disadvantaged children. (Pintelon et al., 2013). A study in Jamaica discovered that earnings of those disadvantaged children who attended pre-school education were $25 \%$ higher than those who didn't twenty years after. (Gertler et al., 2014) Successful implementation of social investment at an early age reduces crime, increases the number of school graduates and skilled workers in the future, as well as gives individual benefits - better health, a lower risk that an individual will engage in "risky behaviour" and greater civil and social involvement. (Campbell et al., 2014)That is why building an early base of skills that promote later-life learning and engagement in school and society is a good strategy. (Kautz et al., 2014)

The main forms of social investment for children in the preschool age are high quality ECEC, as well as parental leaves. That is why this research will focus exactly on these forms of support. The aim of this research was to analyse availability of early childhood education services and parental leaves in Vidzeme region (Latvia) for a case study. And the main questions that authors wanted to answer was, what tendencies can be observed when it comes to family benefits, ECEC service availability and quality in Latvia and Vidzeme region in particular, as well as is there already any evidence that these investment policies have some positive impact on children development.

The aim of the research was achieved through interviews, surveys and data analysis. This research study selected information about development particularly in Vidzeme region, because the fertility rate is among the lowest in Latvia and in previous research studies social investment has been linked with fertility rates. (University of Latvia, 2013)

\section{Methodology}

Four municipalities were selected for analysis in Vidzeme region. Two municipalities were those with the highest birth rate - the municipalities of Beverina and Smiltene, and two with the lowest birth rate - the municipalities of Cesvaine and Strenči. Since there is one city of national significance in Vidzeme 
region, for a deeper view of the situation, an analysis of social investments that are available to parents with pre-school age children in Valmiera was performed as well.

Policy document and statistic data analyses for the selected municipalities and Valmiera, as well as Latvia as a whole, were conducted. 16 interviews with education institution representatives, local authorities regarding education and social matters were conducted in the period from 2014 to 2017. Statistic data, for example, the number of children participating in pre-school education in the researched period, was collected from ECEC institutions and municipalities which participated in the research too.

For the better understanding of how parents in Vidzeme region evaluate social investment policies on pre-school age children, a survey of parents was held in eleven pre-school education institutions in 2014, gathering 392 responses (see Table 1)

Table 1 Information about a survey of parents held in 2014 (Reima, 2014)

\begin{tabular}{|c|c|c|c|}
\hline City/ Municipality & $\begin{array}{c}\text { ECE institution } \\
\text { name }\end{array}$ & $\begin{array}{c}\text { Number of } \\
\text { distributed } \\
\text { questionnaires }\end{array}$ & $\begin{array}{c}\text { Filled in } \\
\text { questionnaires }\end{array}$ \\
\hline \multirow{5}{*}{ Valmiera } & Sprīdītis & 65 & 47 \\
\hline & Buratino & 90 & 37 \\
\hline & Vālodzīte & 95 & 35 \\
\hline & Krācītes & 61 & 37 \\
\hline & Total & 311 & 156 \\
\hline \multirow{3}{*}{$\begin{array}{c}\text { Smiltene } \\
\text { municipality }\end{array}$} & Palsmanes PII & 62 & 35 \\
\hline & PII P̄̄lādzītis & 120 & 78 \\
\hline & Total & 182 & 113 \\
\hline $\begin{array}{c}\text { Beverīna } \\
\text { municipality }\end{array}$ & Pasacina & 71 & 35 \\
\hline \multirow{4}{*}{$\begin{array}{c}\text { Strenči } \\
\text { municipality }\end{array}$} & Minkāni & 52 & 33 \\
\hline & Dzērvītes & 38 & 18 \\
\hline & Sprīdīšsi & 6 & 2 \\
\hline & Total & 96 & 53 \\
\hline $\begin{array}{c}\text { Cesvaine } \\
\text { municipality }\end{array}$ & Brīnumzeme & 105 & 35 \\
\hline \multicolumn{2}{|c|}{$\begin{array}{c}\text { Total number of distributed } \\
\text { questionnaires }\end{array}$} & 765 & 392 \\
\hline
\end{tabular}

The research was financed by the EKOSOC-LV project. 
Feliciana Rajevska, Katrīne Reima. Investing in Preschool Age Children - a Case Study of Vidzeme Region (Latvia)

\section{Family and children benefits in the EU and Latvia}

Family, as well as pre-school children's aid policies have changed a lot over time, but since the 1990s social investment policies have become increasingly more urgent. (Cantillon, 2011) Such tendencies are mainly related to the changes in the family model, because the two-earner model has become more urgent. Therefore improvements are targeted to make it easier for parents to reconcile their work and family life. (Ghysels \& Lancker, 2011) Expenditure on cash benefits to persons of working age and their children as a percentage of GDP in many countries has decreased. (Vandenbroucke \&Vleminckx, 2011) In 2013 the EU-28 on average spent about $2.3 \%$ of GDP on family and children benefits (the highest rate was in Denmark - 3.7\%, while in Poland it was only $0.8 \%$ ) (Bradshaw \& Hirose, 2016)

When it comes to Latvia, family policy belongs to the priorities of the central and local governments. This is backed up both by activities and funding. However, social investment policies are still in the transition process. In 2013 Latvia spent $1.173 \%$ of GDP (Estonia $-1.998 \%$ of GDP) on family benefits, while the OECD average rate was $2.14 \%$.(OECD data, homepage)

Latvia has a rather developed family support system. Funding for child-care and total support for families with children has increased by $30 \%$ during the threeyear period 2013-2015. Expenditure growth was mostly affected by an increase in the allowance for childcare and the minimum parental allowance - from $€ 142.29$ to $€ 171.00$, as of 1 January 2014. (The State Social Insurance Agency, homepage)

Starting from 2016, the amount of family state benefits was increased progressively for the second and third (and any next) child and from 2017, the benefits have been increased for the fourth child from EUR 34.14 to EUR 50.07 (4.4 times more than for the first child). Support has increased for families with disable children as well, since the family state benefit for a disabled child until age 7 was increased from EUR 41.62 in 2016 to EUR 106.72 in 2017. (The State Social Insurance Agency, homepage) (Rajevska \&Romanovska, 2016)

Since 1 October 2014 parental leave in Latvia has become friendlier to parents who work, since it can also be combined with income from work - the amount is reduced to $30 \%$ of lost earnings before and after childbirth. (The State Social Insurance Agency, homepage)

\section{ECEC in Latvia and EU}

As mentioned before, another type of social investment for preschoolers, besides family and children benefits, is high quality ECEC, but for these investments to be effective they must be of high quality and available - both in 
terms of infrastructure and service charge / spending conditions. (Ghysels \& Lancker, 2011) Research on ECEC and its availability has shown that if policy makers do not control availability, the Matthew effect can be detected when middle and highest strata of society use services to a higher extend then the lowincome society. It may create a situation where there is a redistribution mechanism deviation in respect to more vulnerable groups in society - working poor families, the unemployed, single-parent families, large families. (Vandenbroucke \& Vleminckx, 2011)

There are differences between European countries in the usage of formal care, especially until a child reaches the age of tree years. For example, in 2010 in Denmark about $68 \%$ of children up to three years of age spent 30 and more hours per week in childcare (78\% from 1 to 29 hours per week), while in Latvia it was $16 \%(17 \%)$, in Estonia 19\% (21\%), in Lithuania $10 \%(12 \%)$, and in countries like Poland, the Czech Republic and Romania it was used by less than $5 \%$ of children up to three years old. The EU-27 average rate was $14 \%(28 \%)$. When it comes to older children, the childcare usage rate is much higher and differences are not so large. For example, in 2010 in Denmark about $76 \%$ of children from three years of age to mandatory school age spent 30 or over hours per week in childcare (90\% from 1 to 29 hours per week), while in Latvia it was $59 \%$ (63\%), in Estonia 85\% (92\%), Lithuania 59\%(65\%). The EU-27 average rate was 44\% (83\%) (Mills et al., 2014).

Consequently, until child is 3 years old, public expenditure on ECEC is much lower than from 3-5 years of age.(OECD -Social Policy Division, 2016) When it comes to total spending on childcare, in 2010 Latvia was third in the EU behind Belgium and Denmark in terms of total public spending on pre-primary education as a percentage of GDP $-0.85 \%$ (European Commission, 2014).

Since 2009 ensuring pre-school availability has belonged to the strategic priorities of Latvia. The main challenges that Latvia's early education system is facing, includes problems like earlier involvement of children in pre-school education and improvement of its availability. In this regard, the OECD has recommended Latvia to expand early childhood education and care (ECEC) services, especially in rural areas. (Ministry of Edcation and Science, 2016).

As statistical data shows, improvements in the situation have been made, since the number of children in ECEC has been growing from 82.200 in 2008 to 92095 in 2015. (Central Statistical Bureau, home page) together with an increase in the number of ECEC institutions: from 2006 to 201476 new municipal and 90 new private institutions have been opened. (Lursoft, home page)There is a tendency for increased usage of ECEC services when it comes to children until three years (inclusive) of age. In 2010 there were 13,639 and in 2015 17,667 children up to two years old (inclusive) attending childcare. On 1September $2015-14.82 \%$ children up to one and half years of age, $69.18 \%$ of two year olds, 
Feliciana Rajevska, Katrīne Reima. Investing in Preschool Age Children - a Case Study of Vidzeme Region (Latvia)

$88.61 \%$ of three year olds, $92.14 \%$ of four year olds, $96.23 \%$ of five year olds and $92.57 \%$ of six year old children participated in preschool education. (Ministry of Education and Science, 2016)

Child care services in Latvia are evolving and growing by creating and improving ECEC services and increasing the number of alternative services that also are co-funded by the government in Latvia (Reima, 2014). Since 2009 private institutions and since 2013 babysitting services were co-funded at the national level till 31 May 2016 to improve ECEC availability. At the end of the programme, in June 2016, there was a shortage of 11,000 places in municipal kindergartens: 8800 children attended private childcare centres and 2200 used the services of nannies, more than a half of those children (6400) lived in Riga (the data of the Ministry of the Environment and Regional Development). Some of the municipalities on voluntary basis continue to provide funding for nannies as well. The largest municipality - Riga city - provides EUR 116.07 benefits on clearly defined conditions to parents of children aged $1 \frac{1 / 2}{2}-3$ years to pay for a nanny, registered in a special register. Thus, the parents receive a possibility to return to the labour market.

Since September 2015, a 3-year innovative project "Vouchers for the provision of child minder service to workers with nonstandard work schedules" has been introduced to promote parental employment and work and family balance. The project is funded by the EU and its aim is to find an optimal child care type for workers with non-standard working hours. This service can be used by parents who have children under 7 years of age if the parents' employer has joined the project. Services must be provided at the time the parent has nonstandard working hours - weekday evenings after midday, from 18:00 at night and weekends. Presently, the 2nd stage of the project is going on. Three urban municipalities (Riga, Jelgava and Valmiera) and eleven enterprises are taking part in the pilot project: in total, 150 employees with non-standard working time (e.g., Riga airport workers, municipal policemen, hospital staff, industrial workers) with children receive coupons that can be used for covering the cost of a nanny or a private kindergarten participating in the programme. Although, for example in Valmiera, the use of the service is low- only 8 children used it, it increases. One of the main reasons why it is low, as Iveta Klavina (a specialist in pre-school education issues in Valmiera) states, is the fact that a company whose employees use the service, has to perform the co-payment and not all of the employers are willing to do that. (Klavina, interview, 2017)

Due to the impact of the crisis, the number of students in ECEC in Vidzeme region declined in 2009 to 8930 (in 2008 it was 9178), but in recent years, despite declining fertility, it has increased and remained steady, indicating that services are becoming more and more popular $(2011$ - 9488, 2015 -9397), as it is observed in Latvia as a whole too. (Central Statistical Bureau, home page) 
Particularly in Vidzeme region, pre-school service availability is promoted through discounts on the lunch fee in ECEC and a differentiated approach to the costs, as well as though transport opportunity for delivery of the child to ECEC institutions, and some municipalities practice flexibility in residence. (Reima, 2014)

Although at national level no support for low-income families is provided, as mentioned before, local authorities practice pre-school discounts for poor, lowincome and large families in Vidzeme region, but the discount size and the coverage range of children have great differences among administrative areas: in municipalities and cities, where children from low-income families are not fully supported by means of the discounts on free lunches, the use of services before the compulsory pre-school education is relatively lower, indicating a lack of inclusiveness, so the Matthew effect can be identified in Latvia. For example, in Seda (Strenči municipality), which as Sandra Āķere (Strenči municipality's ECEC institution director) states, is the poorest area in Strenči municipality (S.Ākere, interview, 2014), 45.,9\% of children in 2014 used ECEC (in Strenči municipality totally $51 \%$ ), while for example in Beverīna municipality it was $64.2 \%$ of children, since poor and large families there can receive $100 \%$ discount on lunches. (Reima, 2014). See Table 2.

Table 2 ECEC discount amount and distribution rules in Vidzeme region 2014 (reviewed again in 2017)

\begin{tabular}{|c|c|c|c|c|c|}
\hline & Valmiera & $\begin{array}{l}\text { Smiltene } \\
\text { municipality }\end{array}$ & $\begin{array}{l}\text { Beverīna } \\
\text { municipality }\end{array}$ & $\begin{array}{l}\text { Cesvaine } \\
\text { municipality }\end{array}$ & $\begin{array}{l}\text { Strenči } \\
\text { municipality }\end{array}$ \\
\hline $\begin{array}{l}\text { Discounts } \\
\text { in ECEC }\end{array}$ & $\begin{array}{l}100 \%- \\
\text { children from } \\
\text { poor families; } \\
50 \% \text { - low- } \\
\text { income } \\
\text { families; } \\
30 \% \text { - large } \\
\text { families } \\
\text { (since } 2008 \text { ) }\end{array}$ & $\begin{array}{l}50 \% \text { - poor } \\
\text { and low } \\
\text { income } \\
\text { families with } \\
\text { children } \\
50 \% \text { - for } \\
\text { large families }\end{array}$ & $\begin{array}{l}100 \% \text { poor } \\
\text { families; } \\
100 \% \text { - for } \\
\text { large families }\end{array}$ & $\begin{array}{l}100 \% \text { poor } \\
\text { families to } \\
\text { compulsory } \\
\text { pre-school } \\
\text { learning ( } 5,6 \\
\text { years); } \\
50 \% \text { - large } \\
\text { families } \\
\text { (since 2012) }\end{array}$ & $\begin{array}{l}100 \% \text { poor } \\
\text { families (if } \\
\text { GMI is not } \\
\text { received) } \\
\text { (since } 2013 \text { ) }\end{array}$ \\
\hline
\end{tabular}

As regards the quality of services, one of the ways it can be evaluated is through statistic data on twice and/or thrice time repeaters of first grade in Latvia. Data shows that there has been remarkable decrease in twice or thrice time repeaters. If we analyse, for example, the academic year 2007/2008, about $3.8 \%$ of first grade students had to repeat studies in first grade two or three times, while in 2015/2016 there were only 1.67\%.(Central Statistical Bureau, home page) The percentage has decrease, and as I. Kḷavina pointed out, over time there has been 
increase in demands for children who start attending school as well. If some years ago it was not obligatory to acquire literacy at a pre-school institution, now it is. Demands for children has increased in recent years, but despite that learning outcomes in first grade have been improving. (Kḷavina, interview, 2017)

We also have to take in consideration that at the moment it is planned to shorten the pre-school education by one year - from 1 September 2018, 6-yearolds begin schooling after their basic education programmes. I.Klavina expresses an opinion that although it depends on parents, a child should attend pre-school education from one and half years, because she has observed a tendency that those who start to attend preschool educational institutions before 5 years of age are better developed and successively better prepared for the acquisition of basic education. This can be explained by the fact that parents do not always understands their child's abilities, the development needs of each specific age group and are not able to provide quality education they need.(Kḷvina, interview,2017) In Vidzeme region both local government representatives and parents evaluated ECEC quality as good in the survey- 78.4\% of the respondents in Valmiera rated it as very good or good quality service, $77.2 \%$ in Smiltene municipality, $88.6 \%$ in Beverīna municipality, $81.1 \%$ in Strenči municipality and $97.2 \%$ in Cesvaine municipality. So these data additionally confirms that investment in pre-school age is of high quality and already has investment return in Latvia. (Reima, 2014)

\section{Conclusions}

- In Latvia, social investment policies on early childhood education has good progress during the last years.

- Family and children benefits that improve the family and work balance have been increased and some new forms of support have been introduced - a parental benefit can also be combined with income from work.

- ECEC availability has improved, and it has positively influenced the use of services, especially for children that have not reached three years of age.

- $\quad$ The Matthew effect can be identified in the poorer areas of Vidzeme region and Latvia, since there are differences in support offered to children from disadvantaged families. According to previous studies, particularly these groups of children would benefit the most from social investment in preschool age.

- $\quad$ Social investment in pre-school age children is of high quality and already has produced some returns in Latvia. A positive impact can be observed when it comes to a child's development, especially the child's preparedness for the first grade, despite the growing demands for children when they start to attend a primary school. 


\section{References}

Bradshaw, J., Hirose, K. (2016). Child Benefits in Central and Eastern Europe. Downloaded from http://www.ilo.org/wcmsp5/groups/public/---europe/---ro-geneva/---sro-budapest/ documents/publication/wcms_532424.pdf

Campbell, F., Conti, G., Heckman, J.J., Moon, S.H., Pinto,R., Pungello, E., Pan, Y. (2014). Early Childhood Investments Substantially Boost Adult Health. Downloaded from http://home.uchicago.edu/rodrig/ScienceABC.pdf

Cantillon, B. (2011). The paradox of the social investment state: growth, employment and poverty in the Lisbon era. Journal of European Social Policy. Downloaded from Sage publication.

Central Statistical Bureau (home page) Selection: Education. Retrieved: 27.01.2017. Available: http://data.csb.gov.lv/pxweb/en/Sociala/Sociala_ikgad_izgl/?tablelist=true\&rxid=a79 839fe-11ba-4ecd-8cc3-4035692c5fc8

Europe Commision (2014). Key Data on Early Childhood Education and Care in Europe, Downloaded from https:/www.google.lv/url? $\mathrm{sa}=\mathrm{t} \& \mathrm{rct}=\mathrm{j} \& \mathrm{q}=\&$ esrc $=\mathrm{s} \&$ source $=\mathrm{web} \&$ $\mathrm{cd}=1 \& \mathrm{cad}=\mathrm{rja} \& u a c t=8 \& \mathrm{ved}=0 \mathrm{CCUQFjAA} \& u r l=\mathrm{http} \% 3 \mathrm{~A} \% 2 \mathrm{~F} \% 2 \mathrm{Feacea}$.ec.europa.eu $\% 2$ Feducation\%2Feurydice\%2Fdocuments\%2Fkey_data_series\%2F166EN.pdf\&ei=3U y2VL2iK6OiygO0_YHYDw\&usg=AFQjCNEbVYNOu9oIy6HpOUR4HDXxVnVt5Q \&sig2=8soPTg0oM9XHnDSzZXJXqw\&bvm=bv.83640239,d.bGQ

Gertler, P., Heckman, J., Pinto, R., Zanolini, A., Vermeersch, C., Walker, S., Chang, S.M., Grantham-McGregor, S. (2014). Labour market returns to an early childhood stimulation intervention in Jamaica. Downloaded from http://home.uchicago.edu/rodrig/Jamaica.pdf

Ghysels, J., Lancker, W. V. (2011). The unequal benefits of activation: an analysis of the social distribution of family policy among families with young children. Journal of European Social Policy 21: 472. Downloaded from Sage publication.

Kautz, T., Heckman, J.J., Diris, R., Weel, B., Borghans, L. (2014). Fostering and Measuring Skills: Improving Cognitive and Non-Cognitive Skills to Promote Lifetime Success. Downloaded from https://www.oecd.org/edu/ceri/Fostering-and-Measuring-SkillsImproving-Cognitive-and-Non-Cognitive-Skills-to-Promote-Lifetime-Success.pdf

Lursoft (home page). Privāto pirmsskolas izglìtības iestāažu nozare Latvijā vēl nav piesātināta. Downloaded from http://blog.lursoft.lv/2014/05/26/Privato-pirmsskolas-izglitibasiestazu-nozare-Latvija-vel-nav-piesatinata/?link=press/2014/05/26/Privato-pirmsskolasizglitibas-iestazu-nozare-Latvija-vel-nav-piesatinata

Mills, M., Präg, P., Tsang, F., Begall, K., Derbyshire, J., Kohle, L., Miani, C., Hoorens, S. (2014). Use of childcare services in the EU Member States and progress towards the Barcelona targets. Downloaded from http://ec.europa.eu/justice/gender-equality/ files/documents/140502_gender_equality_workforce_ssr1_en.pdf

Ministry of Edcation and Science (2016). Pirmsskolas izglìtība. Downloaded from http://www.izm.gov.lv/images/OECD/IZM_Pirmsskola_200516_OECD.PDF

Morel,N., Palier, B., Palme, J. (2012). Towards a Social Investment Welfare State?: Ideas, Policies and Challenges. The Policy press, Great Britain.

OECD data (homepage). Family benefits public spending. Retrieved: 27.01.2017. Available: https://data.oecd.org/socialexp/family-benefits-public-spending.htm\#indicator-chart

OECD -Social Policy Division (2016). Public spending on childcare and early education.

Downloaded from 
Feliciana Rajevska, Katrīne Reima. Investing in Preschool Age Children - a Case Study of Vidzeme Region (Latvia)

https://www.oecd.org/els/family/PF3_1_Public_spending_on_childcare_and_early_edu cation.pdf

Pintelon, O., Cantillon, B., Bosch, K., Whelan, C. (2013). The social stratification of social risks: The relevance of class for social investment strategies. Journal of European Social Policy. Downloaded from Sage publication.

Rajevska, F., Romanovska, L. (2016). Latvia: both sides of economic recovery success story in "Challenges to European Welfare Systems (ed.Klaus Schubert, Palloma de Villota, Johanna Kuhlman). Springer, p.473-496; ISBN: 978-3-319-07679-9.

Reima, K. (2014). Preschool children's support policy in Vidzeme region (2009-2013): Case Studies. Bachelor thesis, 122 pages

The State Social Insurance Agency (homepage) Selection: For parents Retrieved: 27.01.2017. Available: http://www.vsaa.lv/en/

University of Latvia (2013). Latvija. Pārskats par tautas attīstību 2012/2013: Ilgtspējīga nācija. Downloaded from http://www.szf.lu.lv/fileadmin/user_upload/szf faili/ Petnieciba/sppi/tautas/TAP-makets2013_ar_vaaku.pdf

Vandenbroucke, F., Vleminckx, K. (2011) Disappointing poverty trends: is the social investment state to blame? Downloaded from Sage publication

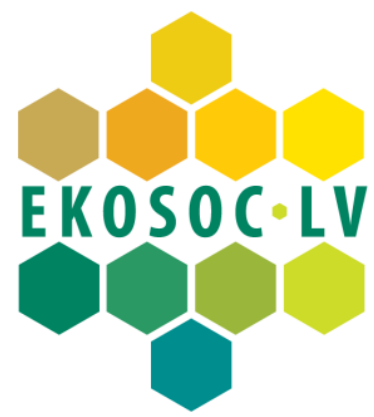

